\title{
Sahaptin: Between stress and tone
}

\author{
Sharon Hargus and Virginia Beavert \\ University of Washington and University of Oregon
}

\section{Pitch accent}

Phonologists have traditionally recognized three basic types of lexical prosodic systems in spoken languages: stress, tone, and pitch accent. The latter has been defined in different ways and its status as a prosodic primitive is currently controversial. Putting the last point aside temporarily, and drawing on McCawley 1978, Zhivov 1978, Beckman 1986, Odden 1999, Alderete 1999, Gomez-Imbert 2001, Hyman 2001, and Yip 2002, pitch accent languages have often been claimed to have the cluster of properties shown in (1):

(1) Typical characteristics of pitch accent languages

- location of accent may or may not be predictable

- $\quad$ surface accentual contrasts on monosyllables are possible

- underlying accentual contrasts on morphemes are possible

- there is typically one accent per domain, though accent shifts are possible

- $\quad$ pitch is predictable from underlying accent

- there is typically a relatively small number of minimal pairs

Hayes 1995:49, in a slight refinement and simplification of (1), defines a pitch-accent language as one:

in which actual contrasts of accentual pattern within the syllable may be found; that is, a heavy syllable may have rising or falling prominence. Examples include Ancient Greek, Lithuanian, Hopi, and some dialects of Serbo-Croatian...In generative phonology, they can be treated as involving tonal representations within the word phonology, either in addition to or instead of metrical representations...Pitch accent languages must satisfy the criterion of having invariant tonal contours on accented syllables, since tone is a lexical property.

Lately Larry Hyman, in a series of publications (Hyman 2006, Hyman 2009, Hyman 2013), has questioned the basic prosodic trichotomy. Hyman 2009, summarizing the literature, notes that the term "pitch-accent...is frequently adopted to refer to a defective tone system whose tone is obligatory, culminative, privative, metrical, and/or restricted in distribution", but also suggesting that "we would do well to avoid using the term pitch accent as a catch-all in favor of direct reference to the properties of...a diverse collection of intermediate word-prosodic systems".

The Yakima dialect of Sahaptin (ykm) (hereafter YS) has been described as a pitch accent language (Hargus and Beavert 2005, Hargus and Beavert 2014) with the properties summarized in (1). In this article we will bring to light new data from reduplicated verbs found in texts. Trisyllabic and longer reduplicated verbs appear to have secondary stress, which is unexpected in a pitch accent language. In $\S 2$ we present background information on Sahaptin and YS prosody. In $\$ 3$ we present and discuss the data involving secondary stress. In $\$ 4$ we provide steps towards a formal analysis of secondary stress. In $\$ 5$ we indicate where future research on YS may provide further support for the analysis. In $\S 6$ we summarize and present conclusions.

\footnotetext{
*We thank the Jacobs Research Funds (grants awarded to Hargus and Beavert) for their support 2009-2016. We thank Native Voices Endowment (grants awarded to Beavert) for their support 2010-2016. Both awards were for research on Sahaptin texts. For comments on the poster presented at AMP 2015, we thank Ellen Kaisse, Sharon Rose, Kie Zuraw, and Adam Albright.
}

(C) 2016 Sharon Hargus and Virginia Beavert

Proceedings of AMP 2015

Completed March 30, 2016 


\section{Background on Sahaptin and Sahaptin prosody}

2.1 Sahaptin Sahaptin (Penutian, Plateau Penutian, Sahaptian) is generally recognized as having three clusters of dialects, following Jacobs 1931 and Rigsby 1965: River, Northeast, and Northwest. Yakima (a.k.a. Yakama), the focus of this article, belongs to the Northwest dialect. Umatilla, which will be briefly contrasted with Yakima, belongs to the River dialect.

2.2 Lexical prosody In YS every lexical word must have an accent. This holds of words of varying degrees of length: content morpheme monosyllables like [kú] 'do, make' and [náf] 'carry inside', ${ }^{1}$ as well as disyllables (e.g. [k'úsi] 'horse'), and longer words (e.g. [k' ajawí] 'mountain lion', [alapífaf] 'death camas'). The only 'words' which lack accent are certain function morphemes, like [ku] 'and', [u:] 'or', and second position clitics like [naf] 1SG and [nataf] 1PL.EXCL. YS thus displays one of the defining characteristics of a stress language, Obligatoriness: "every lexical word has at least one syllable marked for the highest degree of metrical prominence (primary stress)" (Hyman 2006). In YS obligatoriness also holds of roots, whereas affixes are either accented or unaccented.

YS also displays Hyman's second property of a stress language, Culminativity: "every lexical word has at most one syllable marked for the highest degree of metrical prominence". In YS, one and only one syllable is the most prominent. Although roots must have an accent, its location is unpredictable (cf. [ałá] 'claw, finger, toe', [ála] 'paternal grandfather'; [pámta] 'woman's brother's son' (VOC), [pamtá] 'bullfrog, toad'). As mentioned above, affixes are either accented or not (-[mí] GEN vs. -[ki] INST; [pa]- 3PL.NOM vs. [pá]- INV), and accent location in longer affixes is also unpredictable ([pápa]- RECP vs. [piná]- REFL.SG). As evidence of Culminativity in YS, accent shifts from root to (outermost) affix obligatorily (Hargus and Beavert 2002b), except for a small set of "strong roots" (Hargus and Beavert 2006) which fail to shift accent to prefixes. The realization of accent within words which contain more than one underlying accent is predictable, as follows: suffix < strong root < prefix < root (Hargus and Beavert 2006), partially exemplified in (2):

(2) Accent location in morphologically complex words

\begin{tabular}{|c|c|c|}
\hline [tk átat] 'eating' & [májtk ${ }^{\mathrm{w}}$ atat] 'eating breakfast' & [majtk ${ }^{\mathrm{w}}$ atałá] 'breakfast eater' \\
\hline$/ \mathrm{tk}^{\mathrm{w}}$ áta-t] & /máj-tkwáta-t/ & /máj-tk ${ }^{\mathrm{w}} a$ ta-łá/ \\
\hline eat-GER & 'morning'-'eat'-GER & 'morning'-'eat'-AGT \\
\hline root-suffix & prefix-root-suffix & prefix-root-suffix \\
\hline
\end{tabular}

The primary phonetic correlates of YS accent are higher pitch and greater energy (Hargus and Beavert 2005, Jacobs 1931). By the definition of tone language (Hyman 2006) as "one in which an indication of pitch enters into the lexical realisation of at least some morphemes," the following data suggest that YS might be a privative (H vs. 0) tone language: [kú] 'do, make' vs. [ku] 'and'; [náf] 'carry inside' vs. [naf] 1sG; [táftaf] 'merganser' vs. [taf] 1PL.EXCL; [újt] 'first' vs. [u:] 'or', although as discussed above, there is a morphological difference between these morphemes (content vs. function).

2.3 Interaction of lexical prosody with intonation Is YS simply a stress system with pitch as the phonetic correlate of stress (like Turkish, Levi 2005)? An impediment to this view, in favor of the pitch accent analysis, is that word accent interacts with intonation. Declarative sentences are marked by a sentence-final boundary tone $\mathrm{L}$, but this $\mathrm{L}$ does not occur when the sentence-final word ends in an accented syllable on a short vowel, ${ }^{2}$ as in [tk ${ }^{\mathrm{w}}$ alá] 'freshwater fish' (Hargus and Beavert 2014), which can be viewed as a constraint against tonal crowding. A derivational approach to this analysis, showing underlying accent (marked as ẩ) realized as $\mathrm{H}$ tone and word-final L boundary tone, is sketched out in (3) for two of the forms discussed in this section:

\footnotetext{
${ }^{1}$ In this article we transcribe primary accent with acute accent, and the secondary accent (discussed in $\S 3$ ) with a grave accent.

${ }^{2}$ The Sahaptin vowel inventory is /i i: u u: a a: $\dot{i} /$.
} 
(3) Sentence final realizations of two YS words

UR tk ${ }^{\mathrm{w}}$ ală 'freshwater fish'

Culminativity

tk ${ }^{\mathrm{w}}$ ală⿱ 'freshwater fish'

$\mathrm{H}$

Accent

realization

$\mathrm{tk}^{\mathrm{w}} \mathrm{ala}$

Boundary L mẵj-tk ẵta 'morning eat' (i.e. 'eat breakfast')

$\varnothing$

mấj-tk ${ }^{\mathrm{w}}$ ata

$\mathrm{H}$

majtk ${ }^{\mathrm{w}}$ ata

$\mathrm{H} \quad \mathrm{L}$

majtk $^{\mathrm{w}}$ ata

\section{Secondary stress}

Jacobs 1931:117 wrote that in the northwest Sahaptin dialects (recall that these include YS) 'ordinary words have only one syllable accented and no secondary stress... whereas in the Umatilla reservation dialects there may be two, three or four accented syllables to a word'. Somewhat contradicting Jacobs, Rude 1988 wrote of the language as a whole that:

there are three levels of stress -- unstressed, stressed, and secondary stress. None of the published material on the Sahaptin dialects marks secondary stress. It is predictable in bisyllabic reduplication, e.g. [k'ùsik'úsi] 'dog', and is regular in the imperfective past -[shàna] and habitual/frequentative past -[x̣àna]. ${ }^{3}$

Although Rude's ms. includes data from all three dialect regions, the forms in the preceding sentence are not representative of YS. 'dog' is [k'usík'usi], and we have found no discernible secondary stresses in the YS imperfective and habitual past.

The question of secondary stress in YS is one which has vexed us for some time. As discussed in Hargus and Beavert 2002b, when stress shifts from a root to a prefix, if the root contains an accented [i], that vowel is usually deleted (e.g. [ín] 'say, tell', [áwna] '(non-3 p.) told (3 p.)' láw-ín-a) except when adjacent to long sequences of stops. Destressed /i u/ delete under a slightly different set of conditions. As noted in Hargus and Beavert 2002a, when stress shifts from a root to a suffix, these high vowels do not always delete; e.g. [ $\chi^{\mathrm{w}} \mathrm{is}$ sa:t] 'old man', PL [ $\chi^{\mathrm{w}}$ sa:túma $] \sim\left[\chi^{\mathrm{w}}\right.$ isa:túma]. We wondered if such words indicated that a secondary stress is retained when stress shifts from root to suffix, but not when stress shifts from root to prefix.

Putting aside that unanswered question, in our preparation of interlinear glossed text from YS textual recordings (reported on in Hargus and Beavert 2012, Hargus and Beavert 2015), we have lately observed a prosodic phenomenon involving trisyllabic and longer reduplicated verbs which strikes us as secondary stress. The meanings of these verbs are iterative (translated "V over and over", "keep Ving", "V again and again", etc.), and the form of reduplication is total rather than partial. A typical sentence from a text is listed in (4), with secondary stress transcribed where we hear it:

(4) An iterative verb with putative secondary stress from a text sentence

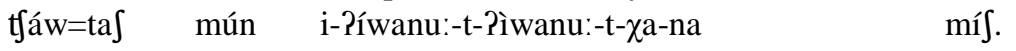

not=1PL.EXC ever 3S.NOM-yell.at-GER-yell.at-GER-HAB-PST at.all

'She never yelled at us (repeatedly).' (Digging, 11:18)

An exhaustive list of the trisyllabic reduplicated verbs we have encountered in about $2500 \mathrm{pp}$. of interlinear glossed text is provided in (5), including the form in (4). ${ }^{4}$ The portion assumed to be the reduplicant is

\footnotetext{
${ }^{3}$ Rude's $\langle$ sh $\rangle=\left[\int\right]$ and $\langle x\rangle=[\chi]$.

${ }^{4}$ Iterative verb reduplication is fairly rare, perhaps because there is a competing morphological strategy, prefixation of /wjá/- 'keep on'. However, iterative verb reduplication is not as rare as the small list in (5) might suggest. Keep in mind
} 
underlined in (5), ${ }^{5}$ and hyphens separate the reduplicated verb from other morphemes in the verb (as well as the reduplicant from the verb stem), but other morphological complexity in the verb is not shown. The forms in (5)a. contain no stressed verbal affixes. The forms in (5)b. contain one or more stressed prefixes, on which the primary stress of the verb lodges. (The forms in a.iii, a.viii and b.iv contain the gerundive suffix $-/ \mathrm{t} /$, which sometimes occurs with verbal reduplication. ${ }^{6}$ ) Secondary stresses occur on the reduplicant and verb stem. (5)c. is an unusual example where the narrator kept the primary stress on the verbal reduplicant instead of shifting it to the verb prefix, as seen in the (5)b. forms. It is not clear that there is a secondary stress on the prefix in this form. (5)d. is a form where primary stress occurs on a suffix, with secondary stresses on each member of the reduplicated verb.

(5) YS trisyllabic iterative verbs from texts

\begin{tabular}{|c|c|c|c|c|c|}
\hline & & verbt in isolation & text example & gloss & text reference \\
\hline \multirow[t]{8}{*}{ a. } & $\mathrm{i}$ & $\begin{array}{l}\text { wapák }{ }^{\mathrm{w}} \text { ftik 'grab at (and } \\
\text { miss)' }\end{array}$ & $\begin{array}{l}\text { i-wapák }{ }^{\mathrm{w}} \int \mathrm{tik}- \\
\text { wapàk }^{\mathrm{w}} \int \mathrm{tik}-\int \mathrm{a}\end{array}$ & 'he keeps grabbing at' & Aug79, 20:58 \\
\hline & ii & lamájlak 'dive' & i-lamájlak-lamàjlak-fana & $\begin{array}{l}\text { 'he was diving again } \\
\text { and again' }\end{array}$ & $\begin{array}{l}\text { Beacon Rock, } \\
21: 27\end{array}$ \\
\hline & iii & $\begin{array}{l}\text { Píwanu: 'roar, yell, } \\
\text { holler at' }\end{array}$ & $\begin{array}{l}\text { i-?íwanu:t-?ìwanù:t- } \\
\text { xana }\end{array}$ & 'she used to yell at' & $\begin{array}{l}\text { Digging, } \\
11: 18\end{array}$ \\
\hline & iv & winanín 'run away' & 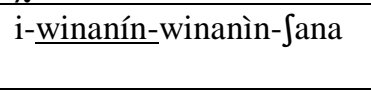 & $\begin{array}{l}\text { 'they were running } \\
\text { away' }\end{array}$ & $\begin{array}{l}\text { Project }(A), \\
29: 15\end{array}$ \\
\hline & $\mathrm{v}$ & & i-winanín-winanìn-fana & $\begin{array}{l}\text { 'they were running } \\
\text { away', }\end{array}$ & $\begin{array}{l}\text { Wenatchee } \\
(\mathrm{A}), 42: 12\end{array}$ \\
\hline & vi & & i-winanín-winanìn-a & 'he kept running away' & $\begin{array}{l}\text { People (B), } \\
38: 22\end{array}$ \\
\hline & vii & wifáwajk 'move across' & 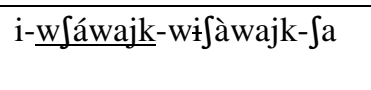 & $\begin{array}{l}\text { 'they're moving back } \\
\text { and forth' }\end{array}$ & $\begin{array}{l}\text { Project }(\mathrm{B}), \\
33: 18\end{array}$ \\
\hline & viii & $\begin{array}{l}\text { wjánawju: 'approach, } \\
\text { come to' }\end{array}$ & $\begin{array}{l}\text { wjánawju:t-wjanawju:t- } \\
\text { na }\end{array}$ & $\begin{array}{l}\text { 'kept coming to see } \\
\text { him' }\end{array}$ & $\begin{array}{l}\text { People (B), } \\
19: 41\end{array}$ \\
\hline \multirow[t]{5}{*}{ b. } & $\mathrm{i}$ & tíq'atJajk tiq'átJajk & 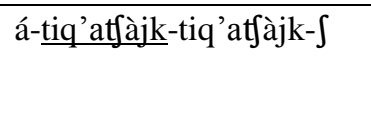 & $\begin{array}{l}\text { 'theirs are scooting } \\
\text { around on their } \\
\text { buttocks' }\end{array}$ & Aug79, 39:28 \\
\hline & ii & $\begin{array}{l}\text { wajáwajk 'run across, } \\
\text { cross with speed' }\end{array}$ & $\begin{array}{l}\text { i-fapá-wajawàjk- } \\
\text { wajawàjk-na }\end{array}$ & $\begin{array}{l}\text { 'he made it cross } \\
\text { quickly back and forth' }\end{array}$ & Flu, 28:50 \\
\hline & iii & & 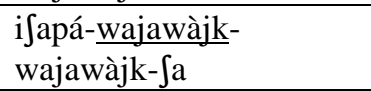 & $\begin{array}{l}\text { 'he's making it cross } \\
\text { quickly back and forth' }\end{array}$ & Flu, 30:07 \\
\hline & iv & $\begin{array}{l}\text { wjánawju: 'approach, } \\
\text { come to' }\end{array}$ & $\begin{array}{l}\text { á-wjanawjù:t- } \\
\text { wjanawjù:t-na }\end{array}$ & $\begin{array}{l}\text { '(they) kept coming to } \\
\text { see him' }\end{array}$ & Jan93, 37:02 \\
\hline & $\mathrm{v}$ & wifáwajk 'move across' & 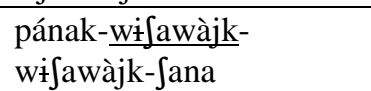 & $\begin{array}{l}\text { 'he was moving ( } 3^{\text {rd }} \text { p.) } \\
\text { back and forth' }\end{array}$ & $\begin{array}{l}\text { Wenatchee } \\
\text { (A), 30:50 }\end{array}$ \\
\hline c. & & wiláwajk 'blow across' & 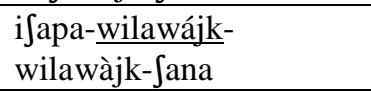 & $\begin{array}{l}\text { 'he was blowing it back } \\
\text { and forth' }\end{array}$ & Flu, 28:50 \\
\hline $\mathrm{d}$. & & áwqanin 'roll around' & àwqanin?àwqaniní:ki & 'rolling around' & $\begin{array}{l}\text { Rock Creek } \\
\text { (A), 29:50 }\end{array}$ \\
\hline
\end{tabular}

In the forms in (5)a. and d., the secondary stress occurs on the same syllable it is found on in the root in isolation. But in the forms in (5)b. and c., the secondary stress occurs on a different syllable: the rightmost

that (5) does not list the monosyllabic and disyllabic iterative verbs which occur in texts. These do not appear to have a secondary stress.

${ }^{5}$ Some noun and adjective stems have partially reduplicated plurals, in which the reduplicant is a prefix: [ká:tnam]

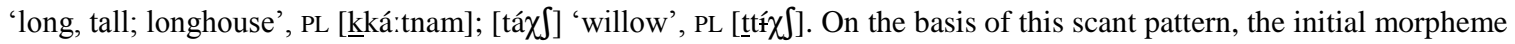
of reduplicated verbs is considered the reduplicant.

${ }^{6}$ This $-[\mathrm{t}]$ is lexicalized with one verb, [kútkut] 'work', historically derived from [kú] 'do, make'. 
heavy syllable in the root. (6) provides confirmation that the primary stress, the highest pitch peak, occurs on the reduplicated verb in (5)c. (The pitch starts to rise at the end of the word in this example because the next word begins with primary stress (high pitch) on the first syllable.)

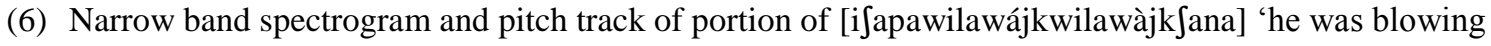
it back and forth'

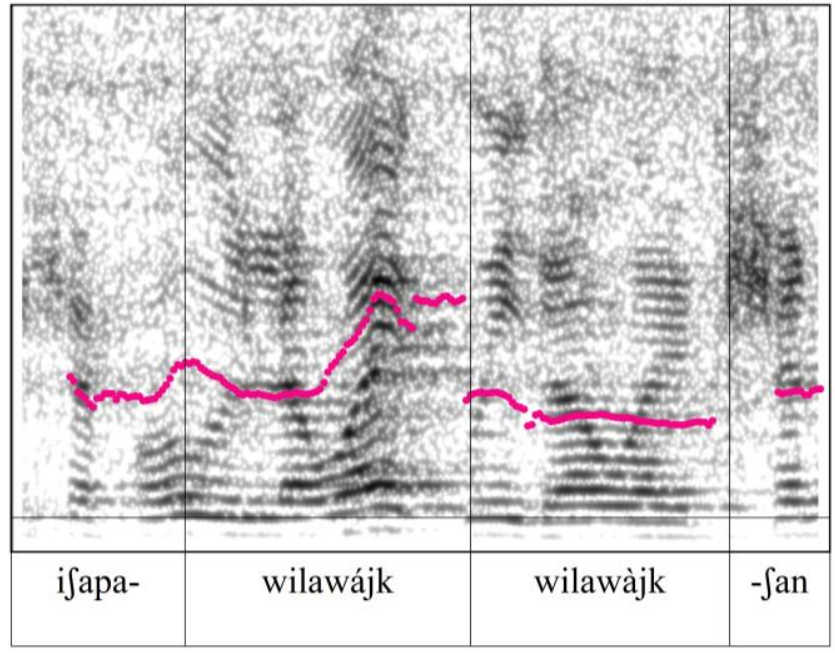

Could the reduplicated forms involve two Phonological Words? If so, we would expect two pitch peaks. But as seen in (6) there is a single pitch peak. An additional spectrogram of the more normal prosodic pattern is given in (7), also providing evidence of a single pitch peak.

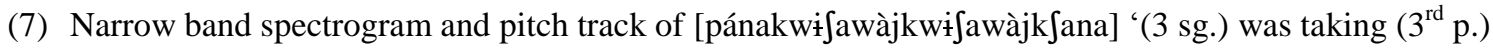
back and forth'

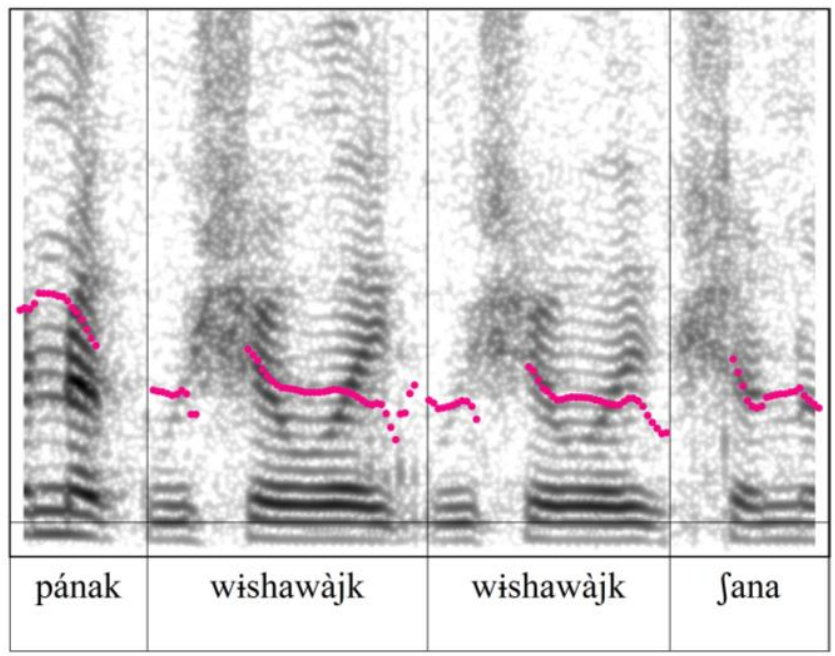

It can also be seen from (6) and (7) that there is no pitch peak on the putative secondary stress. It is virtually indistinguishable in pitch from unstressed vowels within the same word. If not a pitch peak, then how is secondary stressed realized? Although we have not quantified this point, and we think it would be difficult to experimentally confirm, ${ }^{7}$ we think that the phonetic correlate of secondary stress is extra energy,

\footnotetext{
${ }^{7}$ What would be needed for successful elicitation would be an easy to read word list containing an extensive set of contrasts between secondary stress and no stress, like the English near-minimal pair smoking ['smokin], Snoking ['sno,kin] (the latter a blend of the names of two counties, Snohomish and King, of the state of Washington).
} 
or perhaps energy x duration, as suggested by Gordon 2002 in studies of syllable weight. (8) adds intensity to the spectrograms we have been considering so far. It can be seen that the putative secondary stress in [lamàjlak] is not a pitch peak, but does achieve higher intensity over longer duration than the neighboring vowels.

(8) Narrow band spectrogram, pitch peak (speckled) and energy (thin line) contours for [ilamájlaklamàjlakJana] 'he was diving again and again'

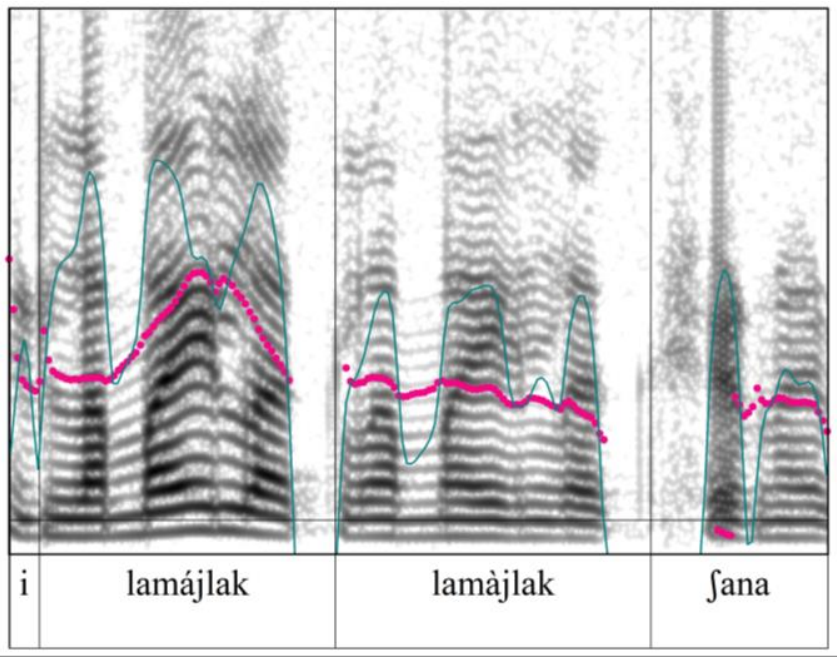

\section{Analysis of secondary stress in reduplicated verbs}

In this section we take steps towards a formal analysis of YS secondary stress, attempting to articulate the conditions under which it is present and where it lodges.

We suggest that in addition to the Phonological Word, within which there can be only one primary stress, there is another word-internal phonological domain, which we call PStem. When this domain is formed, it will preserve an underlying accent, which is not realized as a pitch peak but as energy or perhaps energy $x$ duration, as suggested in $\$ 3$. In (9) we provide a derivational analysis of a pair of forms, one with verbal reduplication and one without. The lexical verb is /wifáwajk/ 'move across, ${ }^{8}$ and there are two stressed prefixes in both forms shown in (9). First, as seen in (9)a, phonological domains are constructed which correspond to the lexical verb (PStem) and the morphosyntactic word (PWord). Next, in (9)b, we propose that the PStem domain is eliminated unless the form contains a PStem "compound", $]_{\text {PStem PStem }}[$. Another condition for PStem survival is that each member of the PStem must have sufficient length, three syllables or more. Culminativity in (9c) then eliminates all but the leftmost accent from each PWord domain. Then there is rhythmic adjustment, labelled Rhythm Rule in (9)d, which adjusts accent location within the PStem, shifting word-internal accents to a heavy syllable within the PStem. ${ }^{9}$ Finally, accents are phonetically realized, PStem internal ones as increased energy, otherwise as high pitch.

\footnotetext{
${ }^{8}$ This verb is at least historically morphologically complex, formed from [wifá] 'move' and [wájk] 'go across', a "bipartite" lexical verb pattern which is very common in Sahaptin and neighboring languages (DeLancey 1996, Beavert and Jansen 2011).

${ }^{9}$ Alternatively to some sort of rhythmic adjustment, perhaps the secondary stress surfaces on [wajk] because it is a root, with underlying accent. See fn. 8. Only more data would resolve this analytical indeterminacy.
} 
(9) Deriving secondary stress in verbal reduplication

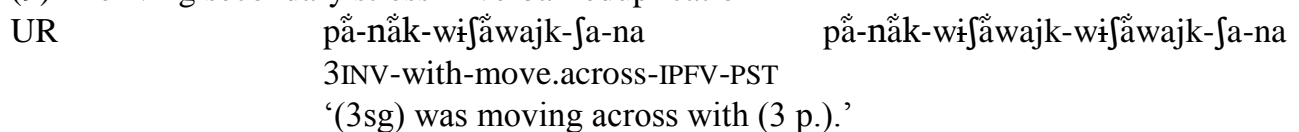

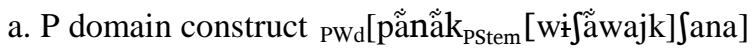

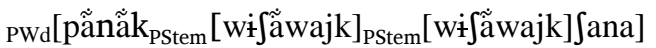

b. PStem adjust $\quad$ Pwd[pẳnẳkwifẳwajkfana]

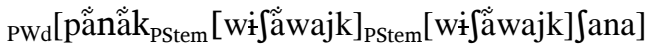

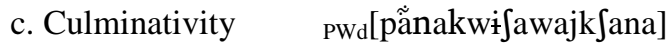

${ }_{P W d}\left[\right.$ pẳnak ${ }_{\text {PStem }}[$ wifã̉wajk]-pstem $[$ wifẳwajk]Jana]

d. Rhythm Rule

PWd[pẳnakwifawajkJana]

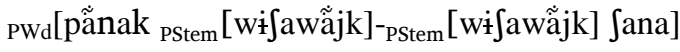

e. Accent

PWd[pánakwifawajkJana]

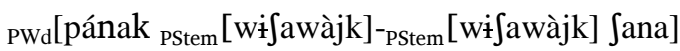

realization

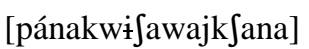

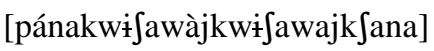

\section{Future research}

As a next step in our understanding of Yakima Sahaptin prosody, we plan to investigate trisyllabic and longer reduplicated nouns and adjectives. With "inanimate" nouns and adjectival modifiers of animate nouns, ${ }^{10}$ total reduplication optionally marking plurality; e.g. [iní:t] 'house', PL [iní:t ini:t]. Our analysis predicts that secondary stress should occur on trisyllabic and longer inanimate nouns and adjectives; e.g. [nísawtas] 'abandoned home, home where someone has died', PL ?[nísawtas nìsawtas], ?[nísawtas nisàwtas]. Future investigation of such words may uncover further confirmation of secondary stress in YS. Because reduplicated nouns and adjectives are morphologically simpler than reduplicated verbs, it may be possible to construct an elicitation list and thereby uncover a phonetic correlate of secondary stress, as compared to no stress.

\section{Implications}

In this short article we have taken an in-depth look at the prosodic properties of a "pitch accent" language like Yakima Sahaptin. We have seen that it displays properties of stress languages (Culminativity, Obligatoriness), and if we are right in our interpretation of texts, secondary stress. But at the same time YS is like a tone language in that lexical accent is phonetically realized as a high tone, and this high tone blocks an intonational low tone (no tonal crowding).

What then do we learn about the status of "pitch accent" language in prosodic typology? One way we might think about languages like YS which lie in between the two extremes of canonical tone and canonical stress language is sketched in (10). Taking a functional approach, suppose we consider that the function of canonical stress to delimit the word as a constituent, whereas the function of tone is primarily to provide lexical contrast. Primary stress in canonical stress languages like Warao thus strongly indicates word edge but does not distinguish lexical items from each other. On the other hand, tone in a language like Yoruba does not provide much information about word boundaries but does help distinguish lexical items from one another. Other languages lie somewhere in between these extremes, perhaps even on a straight line. In YS, primary stress is contrastive, as mentioned in $\S 2$, but not for monosyllables, unless morphology is ignored, and there are not many minimal or near-minimal pairs. On the other hand, primary stress is good at indicating word edge, although sometimes it lodges on the right edge of the word, sometimes on the left edge of the word, so in YS the word demarcating functions of primary stress are perhaps not as clear as in Warao. In Japanese, word prosody has some lexically contrastive function, as in YS, but the word demarcating functions seem even less clear than in YS because pitch patterns can extend over phrases. Swedish (or Norwegian) seems closer to YS in the word demarcative function of prosody but at the same

${ }^{10}$ nouns which are either inanimate (e.g. [p $\int$ wá] 'rock') or animate and immobile ([pátat] 'tree') 
time prosody seems more useful in Swedish than YS in distinguishing lexical items from each other.

(10) Locating "pitch accent" languages by prosodic function

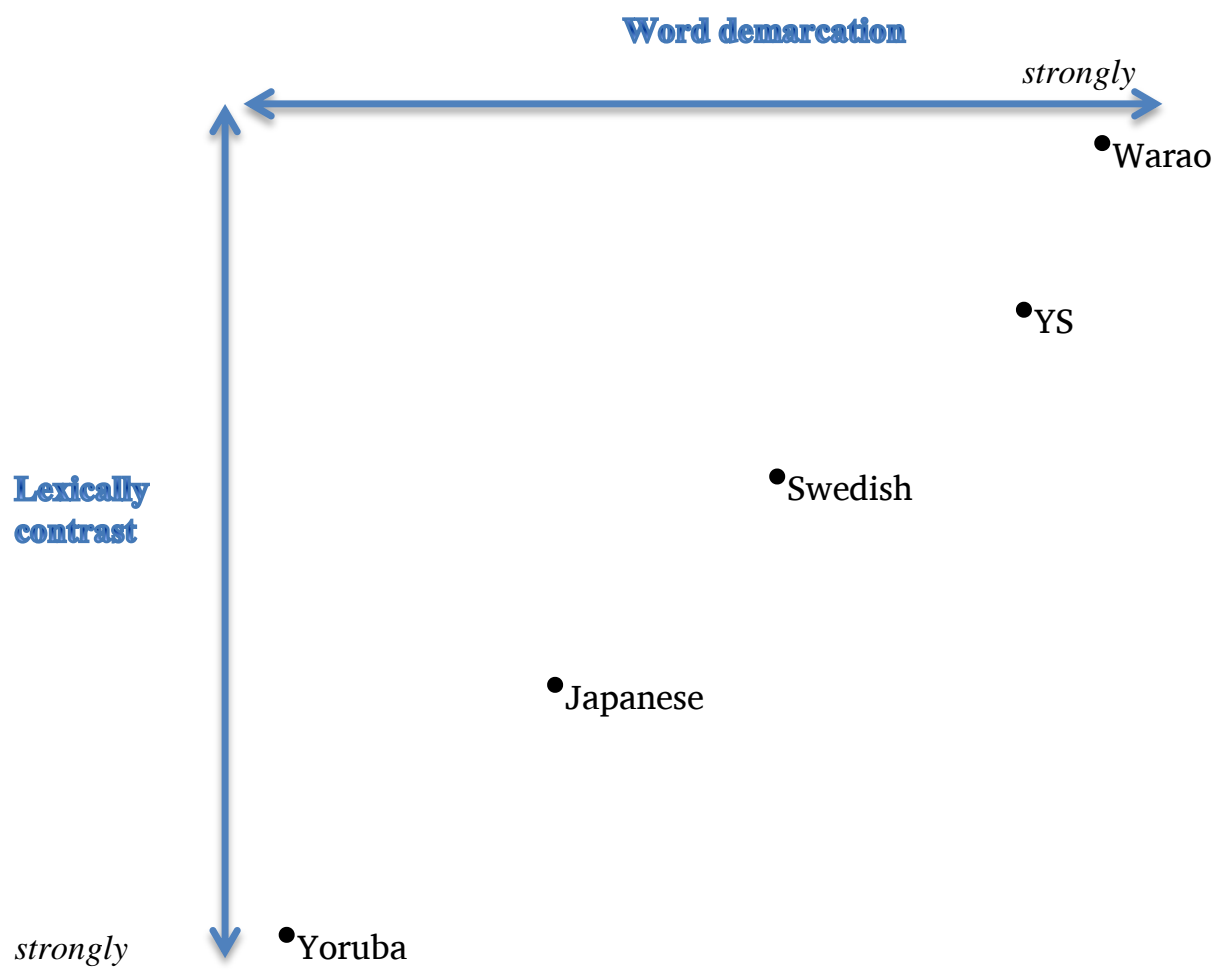

If something like (10) is on the right track, what is needed is some way of quantifying these functions of lexical prosody in each language, and some way of drawing a circle around canonical stress and canonical tone language.

\section{References}

Alderete, John. 1999. Morphologically Governed Accent in Optimality Theory. PhD dissertation, Department of Linguistics, University of Massachusetts, Amherst.

Beavert, Virginia, and Joana Jansen. 2011. 'Yakima Sahaptin bipartite verb stems.' International Journal of American Linguistics 77:121-149.

Beckman, Mary E. 1986. Stress and Non-stress Accent. Dordrecht: Foris.

DeLancey, Scott. 1996. 'Penutian in the bipartite stem belt: disentagling areal and genetic influences.' In Proceedings of the 22nd annual meeting of the Berkeley Linguistics Society: Special session on historical topics in Native American languages, ed. by David Librik and Roxane Beeler. Berkeley: Department of Linguistics, University of California Berkeley.

Gomez-Imbert, Elsa. 2001. 'More on the Tone versus Pitch Accent Typology: Evidence from Barasana and Other Eastern Tukanoan Languages.' In Proceedings of the Symposium "Cross-Linguistic Studies of Tonal Phenomena, Tonogenesis, Japanese Accentology, and Other Topics, ed. by Shigeki Kaji. Tokyo: Institute for the Study of Languages and Cultures of Asia and Africa, Tokyo University of foreign Studies. 369-412.

Gordon, Matthew. 2002. 'A Phonetic Model of Syllable Weight.' Language.

Hargus, Sharon, and Virginia Beavert. 2002a. 'Predictable vs. underlying vocalism in Yakima Sahaptin.' International Journal of American Linguistics 68:316-340.

Hargus, Sharon, and Virginia Beavert. 2002b. 'Yakima Sahaptin clusters and epenthetic [i].' Anthropological Linguistics 44:1-47.

Hargus, Sharon, and Virginia Beavert. 2005. 'A note on the phonetic correlates of stress in Yakima Sahaptin.' In University of Washington Working Papers in Linguistics 24, ed. by Daniel J. Jinguji and Steven Moran. 64-95.

Hargus, Sharon, and Virginia Beavert. 2006. 'High-ranking Affix Faithfulness in Yakima Sahaptin.' In Proceedings of the 25th West Coast Conference on Formal Linguistics, ed. by Don Baumer, David Montero and Michael Scanlon. Somerville, MA: Cascadilla Proceedings Project. 177-185. 
Hargus, Sharon, and Virginia Beavert. 2012. First position clitics in Northwest Sahaptin. Paper presented at Society for the Study of the Indigenous Languages of the Americas, Portland OR.

Hargus, Sharon, and Virginia Beavert. 2014. 'Northwest Sahaptin.' Journal of the International Phonetic Association 44 (3):319-342.

Hargus, Sharon, and Virginia Beavert. 2015. The Sahaptin present perfect in texts. Paper presented at Society for the Study of the Indigenous Languages of the Americas, Portland OR.

Hyman, Larry M. 2001. 'Tone systems.' In Language Typology and Language Universals, ed. by Martin Haspelmath, Ekkehard Koening, Wulf Oesterreicher and Wolfgang Raible. Berlin: Mouton. 1367-1380.

Hyman, Larry M. 2006. 'Word-prosodic typology.' Phonology 23:225-257.

Hyman, Larry M. 2009. 'How (not) to do phonological typology: the case of pitch-accent.' Language Sciences 31 (23):213-238.

Hyman, Larry M. 2013. 'A survey of word accentual patterns in the languages of the world.' Linguistic Typology 17 (1):157-171.

Jacobs, Melville. 1931. 'A sketch of Northern Sahaptin grammar.' University of Washington Publications in Anthropology 4:85-291.

Levi, Susannah V. 2005. 'Acoustic correlates of lexical accent in Turkish.' Journal of the International Phonetic Association 35:73-97.

McCawley, James D. 1978. 'What is a tone language?' In Tone: A Linguistic Survey, ed. by Victoria Fromkin. New York: Academic Press. 113-131.

Odden, David. 1999. 'Typological issues in tone and stress in Bantu.' In Cross-Linguistic Studies of Tonal Phenomena: Tonogenesis, Typology, and Related Topics, ed. by Shigeki Kaji. Tokyo: Institute for the Study of Languages and Cultures of Africa and Asia, Tokyo University of Foreign Studies. 187-215.

Rigsby, Bruce. 1965. Linguistic relations in the Southern Plateau. Ph.D. dissertation, Department of Department of Anthropology, University of Oregon.

Rude, Noel. 1988. A report from the field. In 23rd International Conference on Salish and Neighboring Languages. Eugene, Oregon.

Yip, Moira. 2002. Tone. Cambridge: Cambridge University Press.

Zhivov, V. 1978. 'Restricted Tone Systems versus Pitch Accent Systems.' Estonian Papers in Phonetics:99-101. 